\title{
Effects of Artichoke and Bee Products on Body Weight Gain, Hot Flashes, and Insomnia during Menopause and Climacteric: A Systematic Review
}

\section{Fabiola Mallon-Mercado ${ }^{1}$, Mónica R Jaime-Fonseca ${ }^{\mathbf{1}}$ and Patricia Vergara Aragón ${ }^{2 *}$}

${ }^{1}$ Instituto Politécnico Nacional, Centro de Investigación en Ciencia Aplicada y Tecnología Avanzada, Ciudad de México, México

${ }^{2}$ Departamento de Fisiología, Facultad de Medicina Universidad Nacional Autónoma de México, Ciudad Universitaria, Ciudad de México, México

*Corresponding Author: Patricia Vergara Aragón, Departamento de Fisiología,

Facultad de Medicina Universidad Nacional Autónoma de México, Ciudad

Universitaria, Ciudad de México, México.
Received: June 21, 2021

Published: August 07, 2021

(C) All rights are reserved by Patricia Vergara Aragón., et al.

\begin{abstract}
We sought to evaluate the effect of ingesting artichoke extract and bee products (royal jelly, honey, pollen), or including them in the diet, on the reduction and/or control of body weight, hot flashes, and insomnia during menopause and climacteric. There are only a few clinical reports that specifically correlate the intake of artichoke (or artichoke extract), in combination with bee products, to the decrease in body weight. In this paper, each of these reports will be examined, together with reports of studies carried out in a menopause model of ovariectomized rats.

A bibliographic search was carried out in PubMed and Google Scholar databases, from January 2010 to January 2021. The results were tabulated for an easy comparison of the experiments performed.

Doses of $20 \mathrm{~g}$ Tualang honey and 1,000 mg of royal jelly show benefits in reducing menopausal symptoms such as hot flashes, sweating, and sleep disorders. Royal jelly at a dose of $10 \mathrm{ml} /$ day has an activity that is similar to that of estrogens, in addition to antioxidant, and antihypercholesterolemic activity; these activities result in $70 \%$ improvement of menopausal symptoms. As for artichoke, $1.8 \mathrm{~g}$ of artichoke extract improved the levels of total cholesterol, triglycerides, HDL, and LDL. Hypoestrogenism has been related to physiological changes that are largely responsible for weight gain during menopause, which constitutes a problem for women due to the increase in abdominal fat. Such a situation encourages women to seek alternatives to reduce body weight, hypercholesterolemia, the frequent increase in triglyceride levels, and cardiovascular conditions. In such instance, alternative medicine plays an important role as an option to reduce body weight; specifically, through the reduction of abdominal fat, appetite, and anxiety for sweet foods. Alternative medicine can also provide options to reduce insomnia (specifically improving the quality of REM sleep), irritability, hunger, and appetite (since the consumption of bee products generates a feeling of fullness and satiety). As a result, artichoke and bee products dietary supplementation may represent an effective, inexpensive option for individuals with menopause and overweight.
\end{abstract}

Keywords: Artichoke; Honeybee; Royal Jelly; Menopause; Body Weight; Hot Flashes; Insomnia

\section{Abbreviations}

RJ: Royal Jelly; ALE: Artichoke Leaf Extract; TH: Tualang Honey; HRT: Hormonal Replacement Therapy; OVX: Oophorectomy; SH: Sham Operated

\section{Introduction}

Overweight and obesity are defined as abnormal or excessive accumulation of fat that can be detrimental to health [1]. Obese individuals have a lower quality of life and a shorter life expectancy 
than the average individual. Epidemiological studies have shown that obesity is a risk factor that can be both the cause or consequence of different diseases [2,3].

The treatment of obesity represents a great economic cost for the health system; this condition involves $1 \%$ to $3 \%$ of total health care expenses in most countries ( $5 \%$ to $10 \%$ in the United States), and its costs could increase in the coming years, due to the presence of complications or diseases associated with this condition $[3,4]$.

Currently, Mexico and the United States are the first places in the world's obesity prevalence for the adult population $(30 \%)$, which is around 10 times that of countries such as Japan and Korea (4\%). In Mexico, overweight and obesity show a constant prevalence increase, according to different national surveys [4]. From 1980 to date, the prevalence of obesity and overweight has tripled, reaching alarming proportions $[2,4]$.

According to the National Health and Nutrition Survey (ENSANUT 2018), $40.2 \%$ of the female population over 20 years of age is obese, and more than $76.8 \%$ of this population is overweight $[5,6]$.

Obesity has also been associated with a delay of about a year in the onset of menopause. At each life stage, the development or presence of obesity shows specific characteristics [7-9]. The mechanisms underlying obesity, as a consequence of the imbalance between energy intake and expenditure, are not well understood. However, the effect of overeating and physical inactivity on obesity are irrefutable.

Menopause is defined as the cessation of menstrual periods ( 6 - 12-month amenorrhea). Although menopause is a well-defined event over time, the ovarian function begins to decline a few years before, alternating normal ovulatory cycles with anovulatory periods of variable duration; this period, and up to a year after the last menstrual period, is called perimenopause [9]. Several studies have shown that, regardless of age, menopause is associated specifically with weight gain (estimated to be around 6\%), which occurs in conjunction with an approximate $17 \%$ increase in fat mass [10-12].

The etiology of weight gain during menopause is not completely clear. However, some causes of weight gain are not directly related to menopause, but rather to age. On the other hand, other causes of weight gain depend on the decrease of endogenous estrogens $[7,13,14]$
During childbearing years, the ovarian follicle and the corpus luteum produce $95 \%$ of the circulating estradiol. During menopause, the main sources of endogenous estrogens are the aromatization of androstenedione to estrone and the peripheral conversion of estrone to estradiol $[14,15]$. Estrogens regulate and stimulate the production of different compounds such as leptin, which is a protein secreted in the adipose tissue that is responsible for informing the brain about the magnitude of energy reserves $[14,16]$.

At the same degree of adiposity, women have higher levels of leptin than men. In women at childbearing age, leptin levels are higher during the luteal phase, but its concentration declines after menopause $[7,14,16]$. Estrogens also appear to play a role in appetite regulation [14], as the feeling of satiety is stimulated by cholecystokinin, which in turn is stimulated by estrogens [7]. A positive correlation has been found between cholecystokinin and estrogen levels, and it has been found that cholecystokinin concentration increases after estrogen replacement therapy $[7,17,18]$. Ovarian hormones have a marked effect on the progressive decrease in food consumption during the follicular phase of the menstrual cycle [7] The loss of estrogens after oophorectomy increases food intake and body weight in monkeys, rats, and mice, which suggests that, in general, higher food consumption, accompanied by lack of exercise, contributes to increased adipose tissue after menopause, although there is no conclusive evidence yet [18-21].

In addition, there is a physiological difference in terms of eating habits between men and women; obese men identified foods rich in fat and protein among their favorites, while obese women identified foods rich in fat and carbohydrates (especially foods rich in sugar) among their favorites. People who had proper weight did not show these differences in preference. These differences may be due to sex differences in the hedonic taste experience, and it is thus important to determine if these differences arise before people become obese, or if they are a consequence of obesity $[7,22,23]$.

The lifetime prevalence of psychiatric eating disorders, and of other eating disorder symptoms, are approximately three times higher in women than in men $[24,25]$. Subclinical symptoms of eating disorders are also more common in women than men, recovery from eating disorders is slower in women than in men, and remission rates are higher in women $[7,26,27]$. These eating disorders affect the levels of gonadal steroid hormones [28-30].

Binge eating episodes refer to eating an abnormally large amount of food at one time, causing a feeling of loss of control when 
overeating; binge is an uncontrolled way of eating that occurs especially in girls and women $[29,31]$. A time series analysis of binge eating tendencies and ovarian hormone levels throughout the menstrual cycle suggested that estrogens inhibit emotional bingeing (eating to improve mood) and that progestins counteract the effect of estrogens; i.e, they indirectly stimulate emotional binge eating $[14,15,32,322]$. This is the strongest indication that progestins are clinically important in uncontrolled eating in women [14,32,34].

Figure 1 is a graph made by Asarian., et al. [7], which correlates food consumption (Kcal/day) to each phase of the ovarian cycle. These authors found that sex-specific physiological mechanisms, especially estrogen-mediated effects, play an important role in the development of obesity in women, as well as in the development of pathophysiological consequences of obesity. Therefore, understanding the full impact of the amount of adipose tissue on women's health will require taking into account the hormonal status in each of these processes $[7,14,18]$.

Although weight gain is not the only symptom of menopause, it is perhaps one of the most obvious, and is in turn related to other symptoms such as hot flashes, night sweats, depression, difficulties for starting and/or maintaining sleep, pain during sexual intercourse, hair loss, and forgetfulness [8,9,35]. All of these are

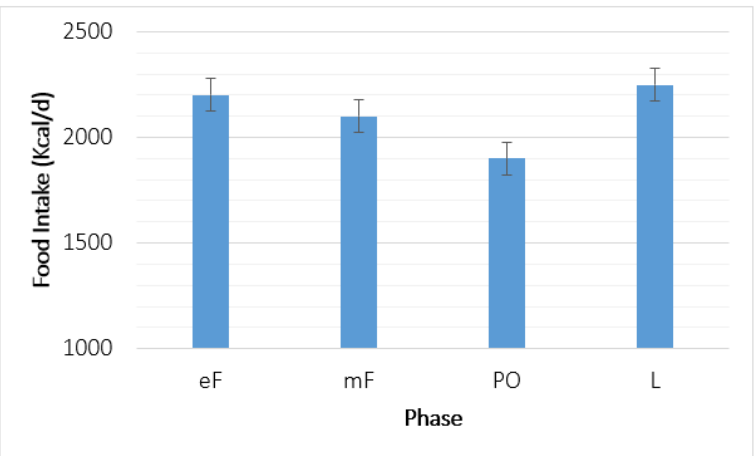

Figure 1: Daily food intake during the different stages of the ovarian cycle in women. Note the progressive decrease in energy intake during the follicular phase around ovulation, and the high level of energy intake during most of the luteal phase. Data are Kcal ingested per day (data represent mean and standard errors of the mean) calculated from three studies in which food intake was measured by weight, and the phase of the cycle controlled with luteinizing hormone tests in urine and menstruation reports ( $\mathrm{n}=34$ women). In each study, data were averaged for the early follicular (eF; 4d), middle follicular (mF; 9d), periovulatory (PO; 4d), and luteal (L; $\sim 11$ d) phases. Asterisks $\left({ }^{*}\right)$ represent significant differences from the luteal phase $[7,14]$. common problems of menopausal women with different treatment approaches, among which the use of natural extracts and/or compounds has gained relevance [17,35-37].

The main pharmacological actions of artichoke (Cynara scolymus) are related to the digestion processes; as it has choleretic, cholagogue, hepatoprotective, and hypocholesterolemic activities. In addition, artichoke has an effect on hyperglycemia, in which caffeoylquinic derivatives seem to intervene, especially cynarin, chlorogenic acid, and sesquiterpenic lactones (e.g., cynaropicrin); these effects have been documented both in experimental and clinical animal studies [38,39]. Cynarin, enhanced by the other components of artichoke, produces intense choleretic (increased bile secretion) and cholagogue (facilitates emptying of the gallbladder) effects, increases diuresis (urine production) and hypoglycemic actions $[40,41]$.

The effects of dried artichoke leaves extracts have been evaluated in patients with dyspepsia, who showed a $71 \%$ reduction of digestive disorders during the treatment period. Cynara scolymus leave extracts have produced a significant improvement of the symptoms of functional dyspepsia (by significantly increasing the amount of bile secretion in the duodenum), and at the same time have shown antiemetic and spasmolytic effects [38].

Several authors have evaluated the effects of the aqueous extract of artichoke leaves on cholesterol levels through clinical trials, in which a reduction in total cholesterol levels has been observed. Similar results have been obtained with healthy volunteers receiving a dose of $1.2 \mathrm{~g}$ of normalized artichoke extract for 12 weeks; these volunteers showed a significant reduction of total cholesterol. The administration of $1.8 \mathrm{~g}$ of artichoke extract per day decreased hyperlipoproteinemia in patients with cholesterol levels above $280 \mathrm{mg} / \mathrm{dL}$ [42].

Apitherapy is a type of alternative medicine that uses natural products from bees, such as honey, propolis, royal jelly, bee bread and bee venom; these products have shown their usefulness for the treatment of various disorders during menopause and postmenopause [35-37], including mood changes, anxiety and depression, vasomotor symptoms (hot flashes, night sweats), osteoporosis, and vaginal atrophy [43]. Royal jelly has been traditionally used to treat menopausal symptoms by rebalancing hormone blood levels, lowering follicle-stimulating hormones (FSH), and increasing estrogen levels in aged mice. One study showed that changes in hormone levels resulting from royal jelly intake increased the number of ovulated oocytes and their quality in aged rats [44]. Purified 
peptides from royal jelly inhibited $\beta$-amyloid 40 and 42 by regulating beta-secretase, which made them useful to improve diseases such as Alzheimer's disease [45]. Additionally, royal jelly improved structural brain imaging and behavioral dysfunctions in cholesterol-fed rabbits. Royal jelly acted through the reduction of body weight, lipid levels, beta-amyloid, and acetylcholinesterase, which was associated with the increase of choline acetyltransferase in the brain [46]. Unfortunately, there are only a few human clinical trials addressing the effects of bee products in the postmenopausal period, as most studies have been conducted in animal models.

In this review, we sought to evaluate the effect of ingesting artichoke extract and bee products (royal jelly, honey, pollen), or including them in the diet, on the reduction and/or control of body weight, hot flashes, and insomnia during menopause and climacteric.

\section{Methodology}

Literature search and study selection criteria

This review was carried out following the PRISMA guidelines(37). PubMed and Google Scholar databases were searched from the time of the study inception to January 2021 without language restrictions. Randomized controlled trials, and in vivo studies in rats from the last 10 years were included. The following text and MeSH keywords were used: "artichoke" "honeybee" "royal jelly" "menopause" "body weight" "hot flashes" "insomnia". Other studies, such as in vitro studies, review articles, and conferences were excluded.

\section{Study selection}

Relevant studies were included according to the following criteria: (1) artichoke or bee products were investigated as an independent intervention, (2) the group under study consisted of women of menopausal age or female rats with and without induced menopause, (3) artichoke or bee products were administered for at least 2 weeks, (4) the study was a randomized placebo-controlled clinical trial or a randomized or an in vivo study in rats with a control group, (5) the study provided sufficient information on outcomes or markers before and after artichoke or bee product interventions in the control and treatment groups. Three authors independently reviewed all articles. Any disagreement was resolved by consensus between the authors.

\section{Data extraction}

Data were collected using a pilot-tested data extraction form that included the following items: 1) study characteristics, includ- ing region, authors, year of publication, sample size, study design, type of study intervention, dose, and duration of the treatment; 2) information on the population, including age, sex, characteristics of the symptoms to be evaluated (BMI, percentage of body fat, test of levels or daily incidences of hot flashes and insomnia). A thorough check was performed to see if there was any disagreement between the extracted data.

\section{Studies}

Included studies

Figure 2 shows the inclusion process of the studies under review. From 65 records identified in the literature, 33 articles were selected for full-text evaluation. Subsequently, nine eligible randomized controlled studies were found to meet the inclusion criteria.

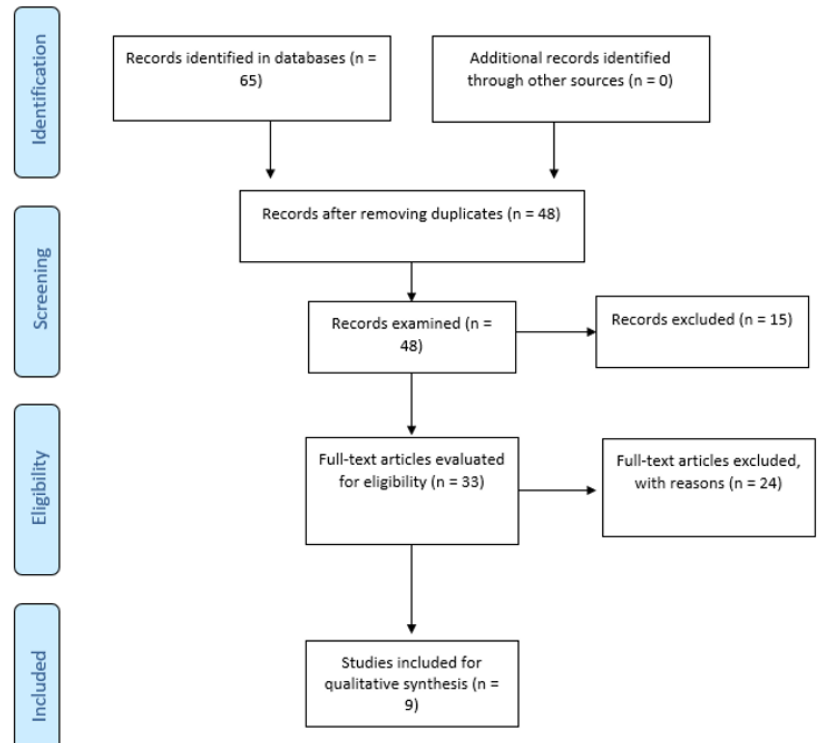

Figure 2

Study characteristics and quality assessment

The studies included in this review were published between 2010 and 2018, the characteristics of these studies are presented in table 1. These studies were held in Malaysia, Japan, the USA, Germany, and Iran. Six studies were conducted in women; three studies consisted of tests performed on rats. The mean duration of the intervention was 11 weeks, and interventions ranged from 2 to 48 weeks. The mean dose of artichoke used was $0.13 \mathrm{~g}$ per day (minimum $0.02 \mathrm{~g}$ and maximum $0.24 \mathrm{~g}$ ) and of bee products $0.6 \mathrm{~g}$ per day (minimum 0.02 and maximum $1 \mathrm{~g}$ ). 


\begin{tabular}{|c|c|c|c|c|c|c|c|c|c|c|}
\hline $\begin{array}{c}\text { Author, } \\
\text { year, coun- } \\
\text { try }\end{array}$ & Item name & $\begin{array}{c}\text { Sample } \\
\text { size }\end{array}$ & Study design & Dose & $\begin{array}{c}\text { Treatment } \\
\text { duration }\end{array}$ & Age & Sex & $\begin{array}{l}\text { Symptoms } \\
\text { evaluated }\end{array}$ & Results & Observations \\
\hline $\begin{array}{c}\text { Siti Zubaidah } \\
\text { Ab Wahab., } \\
\text { et al. } 2018 \\
\text { Malaysia } \\
\text { [47] }\end{array}$ & $\begin{array}{c}\text { Long-term ef- } \\
\text { fects of honey } \\
\text { on cardiovascu- } \\
\text { lar parameters } \\
\text { and T anthropo- } \\
\text { metric mea- } \\
\text { surements of } \\
\text { postmenopausal } \\
\text { women }\end{array}$ & $\begin{array}{c}98 \\
\text { women }\end{array}$ & \begin{tabular}{|} 
Two-arm, \\
double-blind, \\
randomized \\
parallel study \\
comparing \\
Tualang honey \\
(TH) with a \\
honey cocktail \\
(HC) (honey, \\
bee bread, and \\
royal jelly)
\end{tabular} & $\begin{array}{c}20 \mathrm{~g} / \text { day of TH } 20 \mathrm{~g} / \text { day } \\
\text { of HC }\end{array}$ & 12 months & $\begin{array}{l}45-65 \\
\text { years }\end{array}$ & Females & $\begin{array}{l}\text { BMI,\% body fat, waist } \\
\text { circumference, blood } \\
\text { pressure, total cho- } \\
\text { lesterol, triglycerides, } \\
\text { HDL, LDL, blood sugar. }\end{array}$ & $\begin{array}{c}\text { BMI }\left(\mathrm{kg} / \mathrm{m}^{2}\right): \text { No significant differ- } \\
\text { ences. TH = initial 27.44-final } 28.85 . \\
\text { HC = initial } 27.07 \text {-final } 27.04 . \% \\
\text { Fat: No significant differences. TH = } \\
\text { initial 37.21-final 39.61. HC = initial } \\
\text { 39.75-final 39.43. Waist }(\mathrm{cm}): \text { No } \\
\text { significant differences. TH = 86.27 } \\
\text { initial-87.78 final. HC = 87.48 ini- } \\
\text { tial-88 final. }\end{array}$ & $\begin{array}{c}\text { TH promoted } \\
\text { significant changes } \\
\text { in symptoms and } \\
\text { markers different } \\
\text { from BMI,\% body } \\
\text { fat, and waist cir- } \\
\text { cumference. }\end{array}$ \\
\hline $\begin{array}{l}\text { Khatereh } \\
\text { Rezazadeh., } \\
\text { et al. } 2017 \\
\text { Iran [36] }\end{array}$ & \begin{tabular}{|} 
Effects of \\
artichoke leaf \\
extract (ALE) \\
supplementa- \\
tion on meta- \\
bolic param- \\
eters in women \\
with metabolic \\
syndrome: Influ- \\
ence of TCF7L2 \\
- rs7903146 \\
and FTO - \\
rs9939609 \\
polymorphisms
\end{tabular} & $\begin{array}{l}56 \text { wom- } \\
\text { en (7 } \\
\text { dropped } \\
\text { out) }\end{array}$ & $\begin{array}{l}\text { Parallel, } \\
\text { randomized, } \\
\text { double-blind, } \\
\text { placebo-con- } \\
\text { trolled clinical } \\
\text { trial }\end{array}$ & $\begin{array}{c}450 \mathrm{mg} \text { of ALE or placebo, } \\
\text { four times per day }\end{array}$ & 12 weeks & $\begin{array}{l}38-44 \\
\text { years }\end{array}$ & Female & $\begin{array}{c}\text { BMI, waist circumfer- } \\
\text { ence, hip circumfer- } \\
\text { ence, blood sugar at } \\
\text { fasting, triglycerides, } \\
\text { HDL, LDL, total cho- } \\
\text { lesterol, systolic blood } \\
\text { pressure, diastolic } \\
\text { blood pressure, evalu- } \\
\text { ation of the homeosta- } \\
\text { sis model for insulin } \\
\text { resistance, Quantita- } \\
\text { tive Insulin Sensitivity } \\
\text { Check Index }\end{array}$ & \begin{tabular}{|} 
No significant differences in weight, \\
BMI, waist and hip circumference. \\
START VALUES \\
ALE-Placebo \\
BMI: $34.7-32.4$ \\
Weight: $86.6-78.4$ \\
Waist: $106-98.5$ \\
Hip: 116.8-114.5 \\
FINAL VALUES \\
ALE-Placebo \\
BMI: $35.0-32.2$ \\
Weight: $87.3-77.9$ \\
Waist: $105.2-98$ \\
Hip: $117.7-114$ \\
\end{tabular} & $\begin{array}{l}\text { Supplementation } \\
\text { with of the diet } \\
\text { with ALE resulted } \\
\text { in a significant } \\
\text { improvement in } \\
\text { serum triglycerides } \\
\text { levels in carriers } \\
\text { of the A allele of } \\
\text { the polymorphism } \\
\text { rs9939609 of the } \\
\text { FTO gene, a group } \\
\text { of patients with a } \\
\text { higher risk of obe- } \\
\text { sity and Metabolic } \\
\text { syndrome. }\end{array}$ \\
\hline \multicolumn{3}{|c|}{ 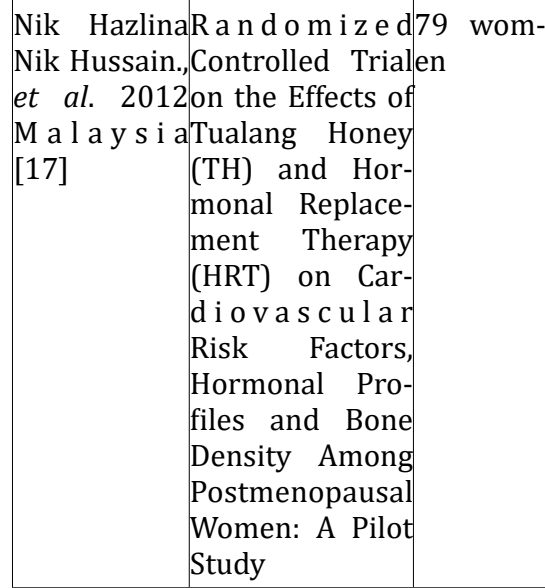 } & \multicolumn{2}{|c|}{$\begin{array}{l}\text { R a n d o m i zed } 20 \mathrm{~g} \text { TH/day. HRT: Femo- } \\
\text { controlled trial,ston }{ }^{\circledast} \text {, also known as Femo } \\
\text { one group with conti } 1 / 5 \text {, (contains } 1 \mathrm{mg} \\
\text { TH and oneof estradiol valerate and } 5 \\
\text { group with HRT mg of dydrogesterone) }\end{array}$} & & \multicolumn{2}{|c|}{$\begin{array}{l}55-59 \text { Female } \\
\text { years }\end{array}$} & $\begin{array}{l}\text { Systolic BP, diastolic } \\
\text { BP, body mass index,l } \\
\text { waist circumference, } \\
\text { TC, TG, LDL-C, HDL-C, } \\
\text { FBS, FSH, LH, estra- } \\
\text { diol, testosterone }\end{array}$ & $\begin{array}{l}\text { No significant differences in weight, } \\
\text { BMI, and waist circumference. } \\
\text { START VALUES } \\
\text { TH-Control } \\
\text { BMI: } 27.73-27.62 \\
\text { Waist: } 86.53-85.56 \\
\text { FINAL VALUES } \\
\text { TH-Control } \\
\text { BMI: } 27.34-27.83 \\
\text { Waist: } 89.18-89.13\end{array}$ & $\begin{array}{l}\text { Systolic BP and LDL } \\
\text { values were lower in } \\
\text { the TH group. }\end{array}$ \\
\hline $\begin{array}{l}\text { Zhiyi Qiang., } \\
\text { et al. 2012 } \\
\text { USA [49] }\end{array}$ & \begin{tabular}{|c|} 
Artichoke \\
Extract (ALE) \\
Lowered Plasma \\
Cholesterol and \\
Increased Fecal \\
Bile Acids in \\
Golden Syrian \\
Hamsters
\end{tabular} & $\begin{array}{l}64 \text { Ham- } \\
\text { sters (32 } \\
\text { males, } 32 \\
\text { females) }\end{array}$ & \begin{tabular}{|}
4 groups \\
formed by Con- \\
trol and Treat- \\
ment for males \\
and females
\end{tabular} & $\begin{array}{c}4.5 \text { g of ELA/kg food. } 0.24 \\
\text { g of ALE/Kg B.W. }\end{array}$ & 42 days & 8 weeks & $\begin{array}{c}\text { Male and } \\
\text { female }\end{array}$ & $\begin{array}{l}\text { Weight, Total choles- } \\
\text { terol, HDL, Non-HDL, } \\
\text { Triglycerides, Bile } \\
\text { acids, Neutral sterols }\end{array}$ & $\begin{array}{l}\text { Weight: No significant differences in } \\
\text { weight. Females: } \\
\text { Control }=128.3 \pm 4.5 \mathrm{~g} \text {, Treatment }= \\
125.9 \pm 7.1 \mathrm{~g}\end{array}$ & $\begin{array}{l}\text { There was a sig- } \\
\text { nificant decrease } \\
\text { in symptoms and } \\
\text { markers different } \\
\text { from weight. }\end{array}$ \\
\hline $\begin{array}{l}\text { A. Minami., } \\
\text { et al. 2016 } \\
\text { Japan [50] }\end{array}$ & \begin{tabular}{|c|} 
Improvement \\
of neurological \\
disorders in \\
postmenopausal \\
model rats by \\
administration \\
of royal jelly (RJ)
\end{tabular} & 43 rats & \begin{tabular}{|c|}
4 groups: Sham, \\
OVX, OVX + RJ, \\
OVX + 17B- \\
estradiol
\end{tabular} & $\begin{array}{l}\text { 17B-estradiol patch, } \\
0.25 \mathrm{mg} / 90 \text { days; RJ, } \\
10 \mathrm{ml} / \mathrm{kg} \text { B.W./day }\end{array}$ & 82 days & $\begin{array}{c}\text { Not } \\
\text { specified }\end{array}$ & Female & $\begin{array}{l}\text { Body weight, brain } \\
\text { and uterus; myelin } \\
\text { protein and galacto- } \\
\text { lipid content, includ- } \\
\text { ing galactosylce- } \\
\text { ramide and sulfatide; } \\
\text { depression }\end{array}$ & $\begin{array}{l}\text { Weight: There were significant differ- } \\
\text { ences. Sham }=205 \mathrm{~g}, \\
\text { OVX }=230 \mathrm{~g}, \mathrm{OVX}+\mathrm{RJ}=220 \mathrm{~g}, \mathrm{OVX}+ \\
\mathrm{E}=190 \mathrm{~g}\end{array}$ & $\begin{array}{l}\text { RJ demonstrated } \\
\text { significant effects } \\
\text { on symptoms and } \\
\text { markers different } \\
\text { from weight. }\end{array}$ \\
\hline $\begin{array}{lr}\text { Siti } & \text { SM } \\
\text { Zaid., } & \text { et al. } \\
2010 \text { Ma- } \\
\text { laysia } & \text { [49] }\end{array}$ & $\begin{array}{l}\text { The effects } \\
\text { of Tualang } \\
\text { honey (TH) } \\
\text { on female re- } \\
\text { productive } \\
\text { organs, tibia } \\
\text { bone and hor- } \\
\text { monal pro- } \\
\text { file in ovari- } \\
\text { e cto m i s e d } \\
\text { rats-animal } \\
\text { model for } \\
\text { menopause }\end{array}$ & 35 rats & \begin{tabular}{lr|}
2 & control \\
groups & and \\
three & test \\
groups. & Con- \\
trol & groups \\
were & sham \\
operated (SH) \\
and ovariecto- \\
mized & (OVX) \\
rats
\end{tabular} & $\begin{array}{l}\text { Control SH and OVX } \\
\text { rats were fed } 0.5 \mathrm{ml} \text { of } \\
\text { distilled water. The rats } \\
\text { in the test groups were } \\
\text { fed a low dose of TH, } 0.2 \\
\mathrm{~g} / \mathrm{kg}(\mathrm{LTH}) ; \text { a medium } \\
\text { dose, } 1.0 \mathrm{~g} / \mathrm{kg}(\mathrm{MTH}) ; \\
\text { or a high dose, } 2.0 \mathrm{~g} / \mathrm{kg} \\
(\mathrm{HTH}), \text { in } 0.5 \mathrm{ml} \text { of dis- } \\
\text { tilled water. Treatments } \\
\text { were administered by } \\
\text { oral gavage once a day. }\end{array}$ & 2 weeks & $\begin{array}{llll}2 & 2 & 0 & - \\
2 & 4 & 0 \\
\text { gr } & & \text { of } \\
\text { weight }\end{array}$ & Female & $\begin{array}{lr}\text { Body weight, } & \text { Vagi- } \\
\text { nal weight, } & \text { Uter- } \\
\text { us weight, } & \text { Tibia } \\
\text { weight, Estradiol, } \\
\text { Progesterone, Free } \\
\text { Testosterone, FSH, } \\
\text { LH }\end{array}$ & $\begin{array}{l}\text { TH prevented uterine atrophy and } \\
\text { atrophy of the vaginal epithelium, } \\
\text { promoted increased bone density, } \\
\text { and suppressed the increase in } \\
\text { body weight seen in the menopaus- } \\
\text { al state. } \\
\text { Weight: Start-End } \\
\text { Sham: } 229-234 \\
\text { OVX: } 226-261 \\
\text { LMT: } 221-252 \\
\text { MMT: } 229-259 \\
\text { HMT: } 229-258\end{array}$ & \\
\hline
\end{tabular}




\begin{tabular}{|c|c|c|c|c|c|c|c|c|c|c|}
\hline $\begin{array}{c}\text { Karsten } \\
\text { Münstedt., et } \\
\text { al. 2015 Ger- } \\
\text { many [50] }\end{array}$ & $\begin{array}{l}\text { Bee pollen and } \\
\text { honey for the } \\
\text { alleviation of } \\
\text { hot flushes and } \\
\text { other meno- } \\
\text { pausal symp- } \\
\text { toms in breast } \\
\text { cancer patients }\end{array}$ & $\begin{array}{c}46 \text { wom- } \\
\text { en (15 } \\
\text { dropped } \\
\text { out) }\end{array}$ & $\begin{array}{c}\text { Prospective and } \\
\text { randomized } \\
\text { crossover trial: } \\
2 \text { groups, one } \\
\text { with a mixture } \\
\text { of honey + } \\
\text { pollen and the } \\
\text { other only with } \\
\text { honey }\end{array}$ & One tablespoon a day & $\begin{array}{l}14 \text { days, } 14 \\
\text { days break } \\
\text { plus } 14 \text { days } \\
\text { with the } \\
\text { other treat- } \\
\text { ment }\end{array}$ & \begin{tabular}{|c|} 
Older \\
than 60 \\
years \\
with at \\
least 7 \\
months \\
of anti- \\
hormonal \\
treatment
\end{tabular} & Female & $\begin{array}{l}\text { Body mass index, } \\
\text { total cholesterol, } \\
\text { triglycerides, HDL, } \\
\text { LDL, exhaustion, } \\
\text { increased aggressive- } \\
\text { ness, hot flushes when } \\
\text { ingested, itchy lips } \\
\text { and mouth, edema of } \\
\text { the lower extremi- } \\
\text { ties, fine hair, mouth } \\
\text { odor, upper abdomi- } \\
\text { nal pain, arthralgia, } \\
\text { flatulence, disgust } \\
\text { when ingesting the } \\
\text { product, nausea, } \\
\text { vomiting, heartburn, } \\
\text { malaise, headache, } \\
\text { red eyes, more severe } \\
\text { hot flashes, dizzi- } \\
\text { ness, itchy face and } \\
\text { extremities }\end{array}$ & $\begin{array}{c}\text { Initial BMI: } 26.9 \text { average; end results } \\
\text { are not described. For both groups } \\
\text { there was an improvement in symp- } \\
\text { toms (68\% for honey and } 70 \% \text { for } \\
\text { honey + pollen). And markers differ- } \\
\text { ent from body mass index. } \\
\end{array}$ & $\begin{array}{l}\text { There were no } \\
\text { changes in choles- } \\
\text { terol, triglycerides, } \\
\text { HDL, LDL. }\end{array}$ \\
\hline $\begin{array}{c}\text { Seyedeh Na- } \\
\text { zanin Sharif., } \\
\text { et al. } 2018 \\
\text { Iran [49] }\end{array}$ & $\begin{array}{c}\text { Effect of royal } \\
\text { jelly (RJ) on } \\
\text { menopausal } \\
\text { symptoms: A } \\
\text { randomized } \\
\text { placebo- T con- } \\
\text { trolled clinical } \\
\text { trial }\end{array}$ & $\begin{array}{c}200 \\
\text { women } \\
(8 \\
\text { dropped } \\
\text { out })\end{array}$ & $\begin{array}{c}\text { Randomized } \\
\text { placebo-con- } \\
\text { trolled clinical } \\
\text { trial }\end{array}$ & $1,000 \mathrm{mg} \mathrm{RJ} /$ day & 8 weeks & $\begin{array}{c}\text { Age } 45- \\
60 \text { years. } \\
\text { At least } \\
\text { one year } \\
\text { of amen- } \\
\text { orrhea }\end{array}$ & Female & $\begin{array}{c}\text { Body mass index, } \\
\text { depression, irritabil- } \\
\text { ity, heart palpitations, } \\
\text { hot flashes, anxiety, } \\
\text { sexual problems, } \\
\text { sleep disorders, blad- } \\
\text { der problems, muscle } \\
\text { dysfunction, and } \\
\text { vaginal dryness }\end{array}$ & $\begin{array}{l}\text { Initial BMI } 28 \text { average. End results } \\
\text { are not described. An improvement } \\
\text { in menopausal symptoms from } 32 \% \\
\text { to } 19 \% \text { is reported. }\end{array}$ & \\
\hline \begin{tabular}{|c} 
Takashi \\
Asama., et al. \\
2018 Japan \\
{$[50]$}
\end{tabular} & $\begin{array}{c}\text { Royal Jelly (RJ) } \\
\text { Supplementa- } \\
\text { tion Improves } \\
\text { Menopausal } \\
\text { Symptoms Such } \\
\text { as Backache, } \\
\text { Low Back Pain, } \\
\text { and Anxiety } \\
\text { in Postmeno- } \\
\text { pausal Japanese } \\
\text { Women }\end{array}$ & $\begin{array}{c}42 \\
\text { women }\end{array}$ & $\begin{array}{c}\text { Double-blind } \\
\text { randomized } \\
\text { controlled trial } \\
\text { with placebo }\end{array}$ & $\begin{array}{l}200 \mathrm{mg} \text { of RJ/per tablet, } \\
\text { four tablets once a day }\end{array}$ & 12 weeks & $\begin{array}{l}54-58 \\
\text { years }\end{array}$ & Female & \begin{tabular}{|} 
BMI, hot flashes, easy \\
sweating, difficulty \\
for falling asleep, \\
difficulty for staying \\
asleep, irritability, \\
anxiety, often irritated \\
by trifles, feeling un- \\
happy or depressed, \\
fatigue, eyestrain, \\
memory problems, \\
dizziness, palpita- \\
tions, chest tightness, \\
headache, stiff neck, \\
back pain and low \\
back pain, pain in the \\
cold joints, cold hands \\
and feet, leg or arm \\
numbness, and sensi- \\
tivity to sounds
\end{tabular} & $\begin{array}{l}\text { There was no significant difference } \\
\text { in BMI. Regarding hot flashes, there } \\
\text { were significant differences be- } \\
\text { tween the two groups after } 8 \text { weeks } \\
\text { of administration and there were } \\
\text { no significant differences after } 12 \\
\text { weeks of administration. } \\
\text { Hot flashes and sweats were re- } \\
\text { duced from } 13 \% \text { to } 32 \% \text {, and be- } \\
\text { tween } 9 \% \text { and } 21 \% \text { insomnia and } \\
\text { sleep quality. }\end{array}$ & \\
\hline
\end{tabular}

Table 1

In artichoke extract studies, only one clinical trial addressed weight evaluation in women. We found no studies dealing with menopausal women that addressed both weight evaluation and menopausal symptoms. The study carried out by Khatereh Rezazadeh., et al. [47] indicated that a diet supplemented with $1.8 \mathrm{~g}$ of artichoke extract resulted in a significant improvement in serum triglyceride levels in carriers of the A allele of the rs9939609 polymorphism of the FTO gene; patients with this polymorphism are at a higher risk of suffering from obesity and metabolic syndrome.

In the case of studies addressing bee products and their benefits in women with menopause, and in ovariectomized rats (OVX) rats, we found clinical studies evaluating body weight; Siti Zubaidah Ab Waha., et al. [36] reported that $20 \mathrm{~g}$ of Tualang honey or honey cocktail per day improved blood pressure, total cholesterol, triglycerides, HDL, LDL, and blood sugar, although there were no changes in BMI, body fat percentage, or waist circumference. Similar results were reported by Nik Hazlina Nik Hussain., et al. [17]; they found that a dose of $20 \mathrm{~g}$ of Tualang honey per day improved systolic blood pressure and LDL values, without changes in BMI and waist circumference. In in vivo studies with rats, A. Minami., et al. [49] reported that a dose of $10 \mathrm{ml}$ of royal jelly $/ \mathrm{kg}$ B.W. reduced the weight of rats with induced menopause and improved the brain and uterus tissues. On the other hand, Siti SM Zaid., et al. [35] showed that, in rats with induced menopause, Tualang honey at a dose of $0.2-2 \mathrm{~g} / \mathrm{kg}$ b.w. prevented uterine atrophy, atrophy of the vaginal epithelium, promoted increased bone density, and suppressed the increase in body weight observed in the menopausal state; the most effective dose against weight gain was $0.2 \mathrm{~g}$ of Tualang honey $/ \mathrm{kg}$ b.w.

\section{Conclusion}

There is a positive effect of bee products on the symptoms of menopause. The effect of bee products on weight control, or weight reduction, could be beneficial, as inducing or reaching menopause is already a determining factor for weight gain. In the case of artichoke, it is not possible yet to assert its benefits for weight control in women; the potential effects of artichoke are even less clear in women at the menopausal stage.

\section{Acknowledgements}

We are grateful to the scholarship program awarded by the National Council of Science and Technology (CONACYT) for the scholarship; we thank the PAPIIT-DGAPA IT201120 project and the Institutional Stimulus for the Promotion of Researchers (BEIFI) of the Research and Postgraduate Secretariat (SIP) of the IPN.

\section{Conflict of Interest}

The authors declare that they have no conflict of interest in conducting and disseminating this research.

\section{Bibliography}

1. OMS. “Obesidad y sobrepeso” (2018).

2. López-Jiménez F and Cortés-Bergoderi M. “Obesidad y corazón”. Revista Espanola de Cardiologia 64.2 (2011): 140-149.

3. Barrera-cruz A., et al. "Escenario actual de la obesidad en México". Revista Medica del Instituto Mexicano del Seguro Social 51.3 (2013): 292-299.

4. Villa AR., et al. "Estimación y proyección de la prevalencia de obesidad en México a través de la mortalidad por enfermedades asociadas". Gaceta Medica de Mexico 140 (2004): 21-25. 
5. Grabiela Pineda H." Significados de la menopausia y el climaterio. experiencia corporal en un grupo de mujeres en el medio urbano". 9 (2011): 3-15.

6. INEGI INSP S de S. Encuesta Nacional de Salud y Nutrición 1 (2018).

7. Asarian L and Geary N. "Sex differences in the physiology of eating". American Journal of Physiology - Regulatory, Integrative and Comparative Physiology 305 (2013): 1215-1267.

8. Morris DH., et al. "Body Mass Index, Exercise, and Other Lifestyle Factors in Relation to Age at Natural Menopause: Analyses From the Breakthrough Generations Study". American Journal of Epidemiology 175.10 (2012): 998-1005.

9. Pavón De Paz I., et al. "Obesity and menopause”. Nutricion Hospitalaria 21.6 (2006): 633-637.

10. Milewicz A., et al. "Menopausal obesity - Myth or fact?". Climacteric. Parthenon Publishing Group Ltd 4 (2001): 273-283.

11. Toth MJ., et al. "Effect of menopausal status on body composition and abdominal fat distribution". International Journal of Obesity 24 (2000).

12. Franklin RM., et al. "Longitudinal changes in abdominal fat distribution with menopause". Metabolism: Clinical and $E x-$ perimental 58.3 (2009): 311-315.

13. Bellino FL and Wise PM. "Mini review Nonhuman Primate Models of Menopause Workshop 1". Biology of Reproduction 68 (2003): 10-18.

14. Leeners B., et al. "Ovarian hormones and obesity". Human Reproduction Update 23.3 (2017): 300-321.

15. Klump KL., et al. "Ovarian Hormone Influences on Dysregulated Eating: A Comparison of Associations in Women with versus without Binge Episodes". Clinical Psychological Science: A Journal of the Association for Psychological Science 2.4 (2014): 545-59.

16. Levin BE., et al. "Metabolic Sensing and the Brain: Who, What, Where, and How?" Endocrinology 152.7 (2011): 2552-2557.

17. Münstedt K., et al. "Bee pollen and honey for the alleviation of hot flushes and other menopausal symptoms in breast cancer patients". Molecular and Clinical Oncology 3.4 (2015): 869-874.

18. Geary N and Asarian L. "Modulation of appetite by gonadal steroid hormones". Philosophical Transactions of the Royal Society B: Biological Sciences 361.1471 (2006): 1251-1263.

19. Moher D., et al. "Preferred Reporting Items for Systematic Reviews and Meta-Analyses: The PRISMA Statement". PLoS Medicine 6.7 (2009): e1000097.
20. Eckel LA. "The ovarian hormone estradiol plays a crucial role in the control of food intake in females". Physiology and Behavior 104.4 (2011): 517-524.

21. Butera PC. "Estradiol and the control of food intake". Physiology and Behavior 99.2 (2010): 175-180.

22. Stice E., et al. "Youth at risk for obesity show greater activation of striatal and somatosensory regions to food". Journal of Neuroscience 31.12 (2011): 4360-4366.

23. Macdiarmid JI., et al. "The sugar-fat relationship revisited: Differences in consumption between men and women of varying BMI". International Journal of Obesity 22.11 (1998): 10531061.

24. Hudson JI., et al. "The Prevalence and Correlates of Eating Disorders in the National Comorbidity Survey Replication". Biological Psychiatry 61.3 (2007): 348-358.

25. Støving RK., et al. "Gender differences in outcome of eating disorders: A retrospective cohort study". Psychiatry Research 186.2-3 (2011): 362-366.

26. Hilbert A., et al. "How Frequent Are Eating Disturbances in the Population? Norms of the Eating Disorder ExaminationQuestionnaire". Tomé D, editor. PLoS ONE 7.1 (2012): e29125.

27. Striegel-Moore RH., et al. "Gender difference in the prevalence of eating disorder symptoms". International Journal of Eating Disorders 42.5 (2009): 471-474.

28. Baker JH., et al. "The role of reproductive hormones in the development and maintenance of eating disorders". Expert Review of Obstetrics and Gynecology. Taylor and Francis 7 (2012): 573-583.

29. Hirschberg AL. "Sex hormones, appetite and eating behaviour in women". Maturitas. Elsevier 71 (2012): 248-256.

30. Poyastro Pinheiro A., et al. "Patterns of menstrual disturbance in eating disorders". International Journal of Eating Disorders 40.5 (2007): 424-434.

31. Reichborn-Kjennerud T., et al. "Gender differences in bingeeating: a population-based twin study". Acta Psychiatrica Scandinavica 108.3 (2003): 196-202.

32. Culbert KM., et al. "Hormonal Factors and Disturbances in Eating Disorders". Current Psychiatry Reports. Current Medicine Group LLC 18 (2016): 1-16.

33. Yu Z., et al. "Individual effects of estradiol and progesterone on food intake and body weight in ovariectomized binge rats". Physiology and Behavior 104.5 (2011): 687-693. 
34. Rezazadeh K., et al. "Effects of artichoke leaf extract supplementation on metabolic parameters in women with metabolic syndrome: Influence of TCF7L2-rs7903146 and FTOrs9939609 polymorphisms". Phytotherapy Research 32.1 (2018): 84-93.

35. Ab Wahab SZ., et al. "Long-term effects of honey on cardiovascular parameters and anthropometric measurements of postmenopausal women". Complementary Therapies in Medicine 41 (2018): 154-160.

36. Zaid SSM., et al. "The effects of Tualang honey on female reproductive organs, tibia bone and hormonal profile in ovariectomised rats - animal model for menopause". BMC Complementary and Alternative Medicine 10 (2010).

37. Hazlina Nik Hussain N., et al. "Randomized Controlled Trial on the Effects of Tualang Honey and Hormonal Replacement Therapy (HRT) on Cardiovascular Risk Factors, Hormonal Profiles and Bone Density Among Postmenopausal Women: A Pilot Study". Journal of Food Research 1.2 (2012).

38. Mocelin R., et al. "Hypolipidemic and antiatherogenic effects of Cynara scolymus in cholesterol-fed rats". Brazilian Journal of Pharmacognosy 26.2 (2016): 233-239.

39. Lattanzio V., et al. "Globe artichoke: A functional food and source of nutraceutical ingredients". Journal of Functional Foods 1.2 (2009): 131-144.

40. Holtmann G., et al. "Efficacy of artichoke leaf extract in the treatment of patients with functional dyspepsia: A six-week placebo-controlled, double-blind, multicentre trial". Alimentary Pharmacology and Therapeutics 18.11-12 (2013): 10991105.

41. Cao X., et al. "1,5-Dicaffeoylquinic acid-mediated glutathione synthesis through activation of Nrf2 protects against OGD/ reperfusion-induced oxidative stress in astrocytes". Brain Research 1347 (2010): 142-148.

42. Mohamed Abdel Magied M., et al. "Artichoke (Cynara scolymus L.) Leaves and Heads Extracts as Hypoglycemic and Hypocholesterolemic in Rats". Journal of Food and Nutrition Research 4.1 (2016): 60-68.

43. Bălan A., et al. "Royal Jelly — A traditional and natural remedy for postmenopausal symptoms and aging-related pathologies". Molecules. MDPI AG 25 (2020).
44. Pasupuleti VR., et al. "A Comprehensive Review of Their Biological Actions and Health Benefits". Oxidative Medicine and Cellular Longevity. Hindawi Limited (2017).

45. Ali AM and Kunugi H. "Royal jelly as an intelligent anti-aging agent - a focus on cognitive aging and Alzheimer's disease: A review". Antioxidants. MDPI AG 9 (2020): 1-46.

46. Zhang X., et al. "Royal jelly peptides: potential inhibitors of $\beta$-secretase in N2a/APP695swe cells". Scientific Reports 9.1 (2019).

47. Minami A., et al. "Improvement of neurological disorders in postmenopausal model rats by administration of royal jelly". Climacteric 19.6 (2016): 568-573.

48. Ghanbari E., et al. "Royal jelly promotes ovarian follicles growth and increases steroid hormones in immature rats". International Journal of Fertility and Sterility 11.4 (2018): 263269.

49. Sharif SN and Darsareh F. "Effect of royal jelly on menopausal symptoms: A randomized placebo-controlled clinical trial". Complementary Therapies in Clinical Practice 37 (2019): 4750 .

50. Asama T., et al. "Royal Jelly Supplementation Improves Menopausal Symptoms Such as Backache, Low Back Pain, and Anxiety in Postmenopausal Japanese Women". Evidence-based Complementary and Alternative Medicine 2018 (2018).

\section{Volume 5 Issue 9 September 2021 (C) All rights are reserved by Patricia Vergara Aragón., et al.}

